\title{
Pengembangan Soal Higher Order Thinking Skills Berbasis Budaya Jambi
}

\author{
Kamid $^{1}$, Rikhel Saputri ${ }^{2}$, Bambang Hariyadi ${ }^{3}$ \\ ${ }^{1,2}$ Program Studi Pendidikan Matematika, Fakultas Ilmu Pendidikan, Universitas Jambi, \\ Jl. Raden Mattaher No. 21 Ps. Jambi, Kec. Jambi Timur, Jambi, Indonesia \\ rikhelsaputri@gmail.com
}

\begin{abstract}
The aim of the research was to provided good Higher Order Thinking Skills (HOTS) questions based Jambi culture in subject 3D flat shapes for 8th class students' of Junior High School. The method of the research was developmental research design. This study consists of two stages, which were preliminary stage consisting of analysis and design, and formative evaluation stage consisting of Expert Review, one to one, Small Group and Field Test. The data were collected by documentation, walkthrough, questioner and test. The result of the research was a sets were valid, practical 10 question HOTS of Jambi culture and having potential effect. The validity of content, construct and language was based on expert judgment, the practicality was measured and questionnaires in Small Group and the potential effect was based on analysis of student answers in Field Test.
\end{abstract}

Keywords: HOTS questions, Jambi Culture, 3D Flat Shape

\begin{abstract}
Abstrak
Penelitian ini bertujuan untuk menghasilkan soal HOTS berbasis budaya Jambi pada materi bangun ruang sisi datar kelas VIII yang baik. Metode penelitian yang digunakan adalah Design research tipe development study. Penelitian ini terdiri dari dua tahap, yaitu tahap persiapan (preliminary) yang terdiri dari analisis dan desain, serta tahap pengembangan (prototyping) yang terdiri dari Expert Review, one to one, Small Group dan Field Test. Teknik analisis data dilakukan dengan dokumentasi, walkthrough, angket dan tes. Hasil penelitian berupa seperangkat soal HOTS berbasis budaya Jambi yang valid, praktis dan memiliki efek potensial sebanyak 10 butir soal. Valid dari segi konten, konstruk dan bahasa berdasarkan penilaian validator, praktis berdasarkan uji coba dan angket pada Small Group dan memiliki efek potensial berdasarkan analisis hasil jawaban siswa pada Field Test.
\end{abstract}

Kata kunci: Soal HOTS, Budaya Jambi, Bangun Ruang Sisi Datar

Copyright (c) 2021 Kamid, Rikhel Saputri, Bambang Hariyadi

$\triangle$ Corresponding author: Rikhel Saputri

Email Address: rikhelsaputri@gmail.com (Jl. Raden Mattaher No. 21 Ps. Jambi, Kec. Jambi Timur, Indonesia)

Received 09 June 2021, Accepted 26 June 2021, Published 02 July 2021

\section{PENDAHULUAN}

Kurikulum 2013 bertujuan agar siswa memiliki kemampuan yang lebih baik dalam melakukan observasi, bertanya, bernalar dan mengkomunikasikan. Hal tersebut diarahkan pada pencapaian kompetensi. Demikian dengan penilaian hasil belajar dan hasil kurikulum, diukur dari pencapaian kompetensi. Agar mencapai hasil belajar yang mampu bersaing dalam menghadapi tantangan masa depan, maka siswa harus memiliki kemampuan berpikir tingkat tinggi, atau Higher Order Thinking Skills (HOTS).

Higher Order Thinking Skills (HOTS) merupakan kemampuan siswa dalam menghubungkan, memanipulasi dan mentransformasikan pengetahuan serta pengalaman yang sudah dimiliki untuk berpikir secara kritis dan kreatif dalam rangka memecahkan masalah pada situasi baru (Rofiah, et al., 2013). Kemampuan berpikir tingkat tinggi dapat terjadi ketika seseorang mengaitkan informasi yang baru diterima dengan informasi yang sudah tersimpan di dalam ingatannya, kemudian menghubunghubungkannya dan/atau menata ulang serta mengembangkan informasi tersebut sehingga tercapai suatu tujuan ataupun suatu penyelesaian dari suatu keadaan yang sulit dipecahkan (Rosnawati, 2009). 
Kemampuan berpikir tingkat tinggi membutuhkan proses berpikir yang luas untuk menemukan tantangan baru dan menuntut seseorang untuk menerapkan informasi atau pengetahuan baru yang dia dapatkan dan memanipulasi informasi untuk mencapai kemungkinan jawaban dalam situasi baru (Heong et al., 2011). Kemampuan berpikir khusus, seperti kemampuan berpikir kritis dan kreatif merupakan dasar dari kemampuan berpikir tingkat tinggi. Salah satu manfaat menggunakan HOTS pada pembelajaran yaitu informasi atau pengetahuan yang dipelajari siswa akan tersimpan lebih lama dibandingkan hanya sekedar menggunakan kemampuan berpikir tingkat rendah atau Low Order Thinking Skills (LOTS).

Menurut Bloom (Anderson et al., 2001) terdapat enam tingkatan berpikir siswa yaitu mengingat (C1), memahami (C2), mengaplikasikan (C3), menganalisis (C4), mengevaluasi (C5), dan mencipta (C6). Level berpikir pada C1, C2, dan C3 adalah level berpikir tingkat rendah (Low Order Thinking). Sedangkan level berpikir pada C4, C5, dan C6 adalah level berpikir tingkat tinggi (Higher Order Thinking) (Masitoh \& Aedi, 2020). Menurut Krathwohl (2002), indikator untuk mengukur kemampuan berpikir tingkat tinggi siswa meliputi kemampuan menganalisis, mengevaluasi dan mencipta. Kemampuan menganalisis (C4) yaitu kemampuan siswa dalam memisahkan konsep ke dalam beberapa komponen dan menghubungkan satu sama lain untuk memperoleh pemahaman atas konsep secara utuh. Kemampuan mengevaluasi (C5) yaitu kemampuan siswa dalam menetapkan derajat sesuatu berdasarkan norma, kriteria atau patokan tertentu. Serta kemampuan mencipta (C6) yaitu kemampuan siswa dalam memadukan unsur-unsur menjadi sesuatu bentuk baru yang utuh dan luas, atau membuat sesuatu yang orisinil.

Pada penyusunan soal-soal HOTS, umumnya menggunakan stimulus. Stimulus merupakan dasar untuk membuat pertanyaan. Stimulus yang disajikan bersifat kontekstual dan menarik. Stimulus dapat bersumber dari isu-isu global seperti masalah teknologi informasi, sosial, ekonomi, kesehatan, dan pendidikan. Stimulus juga dapat diangkat dari persoalan-persoalan yang ada di lingkungan sekitar satuan pendidikan seperti budaya, adat, kasus-kasus di daerah, atau berbagai keunggulan yang terdapat di daerah tertentu (Kristanto \& Setiawan, 2020).

Pendidikan dan budaya adalah sesuatu yang tidak bisa dihindari dalam kehidupan sehari-hari, karena budaya merupakan kesatuan yang utuh dan menyeluruh, berlaku dalam suatu masyarakat dan pendidikan merupakan kebutuhan mendasar bagi setiap inidividu dalam masyarakat. Pendidikan merupakan salah satu manifestasi kebudayaan. Artinya, kebudayaan juga dapat disalurkan melalui pendidikan. Salah satu bentuk kebudayaan adalah budaya lokal atau disebut juga dengan kearifan lokal (Zulfah, 2018).

Elemen-elemen dari budaya sejajar dengan aspek-aspek matematika, ada beberapa bagian aspekaspek matematika tersebut yang terkait dengan pembelajaran matematika. Keterkaitan ini berkaitan dengan konsep-konsep matematika yang dipelajari dalam pembelajaran formal di sekolah. Melalui budaya, khususnya budaya Jambi yang dimasukkan ke dalam pembelajaran matematika siswa dapat memahami pembelajaran matematika dengan mudah dan asyik (Wandari, et al., 2018). Siswa dapat mengetahui lebih banyak tentang budayanya sendiri dan siswa dapat mengintegrasikan budaya kedalam 
materi pembelajaran (Rachmawati, 2012).

Jambi merupakan salah satu provinsi di Indonesia. Budaya lokal Jambi memiliki potensi yang beraneka ragam. Komunitas kebudayaan mempunyai banyak ide matematis yang dapat dikaji dan diteliti pada setiap konteks kegiatan budaya yang dilakukan agar bisa dijadikan sebagai bahan atau sumber pembelajaran matematika yang kontekstual (Sutrimo et al., 2019). Keanekaragaman ini dapat dijadikan sumber referensi dalam pembelajaran matematika di sekolah menggunakan budaya lokal Jambi. Pengintegrasian pembelajaran ialah dengan menggunakan budaya Jambi sebagai media ataupun objek yang dikaitkan dengan masalah-masalah matematika terkhusus pada materi bangun ruang sisi datar. Materi ini dipilih karena banyak siswa yang mengalami kesulitan untuk menyelesaikan masalah-masalah dalam kehidupan sehari-hari yang terkait karena siswa terbiasa hanya untuk pengaplikasian rumus saja. Dengan menyertakan konteks budaya dapat memberikan dan menciptakan pembelajaran bermaknapada setiap konteks kegiatan yang dilakukan agar bisa dijadikan sebagai bahan atau sumber pembelajaran matematika yang kontekstual (Kusmaryono, 2012).

Berdasarkan hasil observasi awal peneliti, diperoleh informasi bahwa selama ini guru memperoleh instrumen evaluasi dari buku paket matematika dan Lembar Kerja Siswa (LKS) di sekolah. Soal yang terdapat pada LKS tersebut bersifat umum seperti yang dapat dilihat pada Gambar 1 berikut.

Sebuah lemari tempat penyimpanan emas batangan yang memiliki ukuran panjang $1,2 \mathrm{~m}$, lebar $0,8 \mathrm{~m}$, dan tinggi $2 \mathrm{~m}$. Bagian dalam lemari tersebut akan diisi seluruhnya dengan emas batangan yang memiliki ukuran $20 \mathrm{~cm} \times 10 \mathrm{~cm} \times 5 \mathrm{~cm}$, banyak emas batangan yang dibutuhkan untuk memenuhi lemari tersebut dan tidak terdapat ruang kosong adalah ... buah

Gambar 1. Soal pada LKS yang Digunakan Di Sekolah yang Diobservasi Peneliti

Soal-soal yang tersedia pada LKS yang digunakan di sekolah yang diobservasi adalah soal bersifat permasalahan rutin. Memang ada beberapa yang berupa soal pemecahan masalah atau penalaran tapi soal tersebut terlalu sukar dan sulit dimengerti oleh siswa. Soal yang tersedia juga tidak banyak kuantitas dan juga variasi soalnya. Konteks soal yang digunakan juga bersifat umum, dan memang tidak menekankan adanya perubahan karakter siswa setelah mengerjakannya.

Dari wawancara diperoleh informasi bahwa siswa tertarik jika diberikan soal-soal yang berkaitan dengan budaya Jambi, baik dari objek wisata, bangunan bersejarah dan makanan tradisional masyarakat Jambi yang sudah menjadi kebiasaan dan sering ditemui dalam kehidupan sehari-hari siswa. Budaya jambi yang dimaksud di atas, dipilih karena memiliki kesesuaian dengan materi yakni bangun ruang sisi datar. Maka diperlukan soal matematika dengan konten budaya lokal. Berdasarkan penelitian yang ada tentang budaya lokal maka perlu dilakukan pengembangan soal-soal berbasis budaya lokal yang mana hal tersebut dapat memberikan efek positif kepada dunia pendidikan.

Adapun penelitian relevan terkait penelitian ini yakni penelitian dari Kamid et al., (2018), dimana dengan menggunakan bahan ajar berbasis budaya Jambi, baik guru maupun siswa akan menemukan 
matematika yang menyenangkan, mudah, dan menarik untuk dipelajari, terutama pada topik geometris. Serta penelitian dari Kamid et al., (2020), dimana unsur etnomatematika dan bentuk geometris bidang datar pada budaya Jambi seperti struktur bangunan Masjid Agung Pondok Tinggi Kota Sungai Penuh dapat dijadikan acuan pengembangan sumber belajar matematika berbasis budaya lokal yang penerapannya diharapkan tidak hanya mengenalkan dan melestarikan budaya lokal, memudahkan siswa dalam memahami geometri bidang datar tetapi juga memberikan kesan dan makna dalam pembelajaran matematika itu sendiri.

Berdasarkan uraian tersebut, tujuan dari penelitian ini adalah mengembangkan soal Higher Order Thinking Skills (HOTS) berbasis Budaya Jambi yang berkategori valid dan praktis serta memiliki efek potensial. Dalam penelitian ini, penggunaan budaya Jambi diintegrasikan dengan soal-soal HOTS. Budaya Jambi yang digunakan ialah bangunan bersejarah, objek wisata serta makanan tradisional yang memungkinkan terkait dengan materi bangun ruang sisi datar. Dengan integrasi yang dilakukan diatas, pembelajaran yang diharapkan dapat terwujud dengan baik dan dapat melatih siswa dalam mengerjakan soal-soal HOTS berbasis budaya Jambi terkhusus pada materi bangun ruang sisi datar.

\section{METODE}

Jenis penelitian yang digunakan dalam penelitian ini adalah penelitian pengembangan dengan metode design research. Model pengembangan yang digunakan adalah model pengembangan tipe formative research Tessmer (Tessmer, 2005). Penelitian ini terdiri dari 2 tahapan yaitu tahap persiapan (preliminary) dan tahap prototyping dengan alur evaluasi formatif (formative evalution) yang terdiri dari penilaian ahli (Expert Review), evaluasi satu per satu (one to one), evaluasi kelompok kecil (Small Group) dan evaluasi uji lapangan (Field Test) (Rusdi, 2018). Penelitian diadakan di kelas VIII SMP Negeri 1 Kota Jambi pada semester genap Tahun Ajaran 2020/2021 bulan Maret - April 2021.

Pada tahap preliminary, peneliti melakukan analisis siswa dan analisis kebutuhan soal HOTS. Kemudian, peneliti mengumpulkan soal-soal HOTS yang ada pada LKS siswa maupun dari sumbersumber lain. Kegiatan ini dilakukan untuk memodifikasi soal-soal HOTS tersebut agar kemudian menjadi soal HOTS berbasis budaya Jambi. Peneliti mendesain instumen tes yang terdiri dari kisi-kisi soal, kartu soal serta kunci jawaban dan rubrik penskoran. Desain produk ini sebagai Prototype I. Prototype I yang telah dibuat dievaluasi sendiri oleh peneliti. Selanjutnya, dilakukan tahap formative evaluation.

Pada tahap formative evaluation, produk yang telah dibuat atau didesain akan dievaluasi. Tahap evaluasi ini produk akan diuji cobakan dalam 4 kelompok, yaitu Expert Review, one-to-one, Small Group dan Field Test. Hasil desain pada Prototype 1 yang dikembangkan diberikan pada Expert Review dan One-to-One yang dilakukan secara paralel. Tahap Expert Reviews merupakan pengujian validitas butir soal oleh pakar (expert). Hal ini dilakukan dengan cara menilai setiap butir soal berdasarkan konten, konstruksi dan bahasa. Saran dan komentar validator dijadikan sebagai masukan untuk revisi Prototype 1.

Bersamaan dengan validasi oleh para ahli, dilakukan tahap one-to-one. Tahap ini melibatkan tiga orang siswa dengan kemampuan beragam (rendah, sedang, dan tinggi). Siswa diminta untuk membaca 
dan mencermati soal kemudian memberi tanggapan tentang keterbacaan dan kejelasan maksud soal. Temuan yang diperoleh pada tahap Expert Reviews dan One-to-One digunakan dalam merevisi Prototype 1. Hasil dari revisi Prototype 1 ini adalah f 2.

Selanjutnya, Prototype 2 diujikan kepada siswa di tahap Small Group. Tahap ini melibatkan enam orang siswa dengan kemampuan beragam untuk menyelesaikan soal-soal Prototype 2. Siswa yang dipilih adalah 2 orang siswa yang memiliki kemampuan rendah, 2 orang siswa yang memiliki kemampuan sedang dan 2 orang siswa yang memiliki kemampuan tinggi. Kemudian, para siswa juga diminta pendapat dan komentar mengenai soal yang telah mereka kerjakan dengan cara mengisi angket terhadap kepraktisan soal. Tahap ini berfokus pada kepraktisan soal-soal yang telah dikembangkan. Temuan pada tahap Small Group digunakan sebagai revisi Prototype 2 menjadi Prototype 3.

Tahap penelitian selanjutnya adalah Field Test. Pada tahap ini Prototype 3 yang telah valid dan praktis diuji cobakan pada 15 siswa kelas VIII SMP Negeri 1 Kota Jambi. Hasil Field Test berupa lembar jawaban siswa yang kemudian dianalisis secara deskriptif untuk mengetahui efek potensial yang dihasilkan dari soal HOTS menggunakan konteks Jambi yang telah dikembangkan dan melalui proses validasi.

Instrumen yang digunakan pada penelitian ini adalah tes menggunakan soal-soal HOTS matematika berbasis budaya Jambi dengan pokok bahasan bangun ruang sisi datar, serta lembar validasi untuk menguji kevalidan tes oleh para ahli. Sedangkan teknik pengumpulan data pada penelitian ini yakni:

1. Dokumentasi,

2. Walkthrough yang dilakukan dengan ahli, kemudian ahli yang ditetapkan akan memberikan komentar atau saran terhadap produk yang telah dikembangkan (Mardhiyanti, et al., 2013). Walkthrough dianalisis secara deskriptif melalui komentar para pakar berupa saran dan komentar sebagai masukan untuk membuat revisi pada pembuatan Prototype 1. Prototype dinyatakan valid jika pakar menyatakan valid ditinjau dari konten, konstruk, dan bahasa yang digunakan (Charmila, et al., 2016).

3. Wawancara mengenai produk yang dikembangkan,

4. Angket, yakni metode pengumpulan data yang dilakukan dengan cara memberi seperangkat pertanyaan atau pertanyaan tertulis kepada responden untuk diberikan respon sesuai dengan permintaan pengguna (Widoyoko, 2020). Angket digunakan untuk mengetahui bagaimana pendapat dan respon siswa terhadap kepraktisan soal setelah dilakukan uji coba produk tersebut pada tahap Small Group. Adapun langkah-langkah menganalisis data tes adalah (Widoyoko, 2011): (1) Memberikan skor dari hasil jawaban dengan skor patokan yang telah ditentukan; (2) Skor yang diperoleh siswa dikonversikan menjadi nilai dalam rentang 1-100 dengan rumus:

$$
\text { nilai }=\frac{\text { skor yang diperoleh }}{\text { jumlah skor maksimum }} \times 100
$$

Setelah diperoleh nilai akhir dari masing-masing siswa, kemudian menentukan nilai rata-rata siswa. Nilai rata-rata yang diperoleh dikonversikan dalam data kualitatif sebagai berikut: 
Tabel 1. Kategori Penilaian Hasil Belajar Siswa

\begin{tabular}{|c|c|c|c|c|c|}
\hline Kategori & $\begin{array}{c}\text { Sangat } \\
\text { Baik }\end{array}$ & Baik & Cukup & Tidak Baik & $\begin{array}{c}\text { Sangat } \\
\text { Tidak Baik }\end{array}$ \\
\hline Nilai & $80-100$ & $66-79$ & $56-65$ & $40-55$ & $0-39$ \\
\hline
\end{tabular}

Berdasarkan analisa nilai angket yang diperoleh, maka dapat ditentukan klasifikasi kepraktisan produk seperti pada tabel dibawah ini (Widoyoko, 2011):

Tabel 2. Kategori Tingkat Kepraktisan Soal

\begin{tabular}{|c|c|}
\hline Rentan Skor & Klasifikasi Kepraktisan \\
\hline$>4,2 \mathrm{~s} / \mathrm{d} \mathrm{5,0}$ & Sangat Praktis \\
\hline$>3,4 \mathrm{~s} / \mathrm{d} 4,2$ & Praktis \\
\hline$>2,6 \mathrm{~s} / \mathrm{d} 4,4$ & Kurang Praktis \\
\hline$>1,8 \mathrm{~s} / \mathrm{d} 2,6$ & Tidak Praktis \\
\hline $1,0 \mathrm{~s} / \mathrm{d} 1,8$ & Sangat Tidak Praktis \\
\hline
\end{tabular}

5. Tes, digunakan untuk memperoleh data tentang efek potensial dari produk yakni soal HOTS berbasis budaya Jambi menggunakan Prototype 3. Adapun langkah-langkah menganalisis data tes adalah (Widoyoko, 2011): (1) Memberikan skor dari hasil jawaban dengan skor patokan yang telah ditentukan; (2) Skor yang diperoleh siswa dikonversikan menjadi nilai dalam rentang 1-100 dengan rumus:

$$
\text { nilai }=\frac{\text { skor yang diperoleh }}{\text { jumlah skor maksimum }} \times 100
$$

Setelah diperoleh nilai akhir dari masing-masing siswa, kemudian menentukan nilai rata-rata siswa. Nilai rata-rata yang diperoleh dikonversikan dalam data kualitatif sebagai berikut:

Tabel 3.Kategori Penilaian Hasil Belajar Siswa

\begin{tabular}{|c|c|c|c|c|c|}
\hline Kategori & $\begin{array}{c}\text { Sangat } \\
\text { Baik }\end{array}$ & Baik & Cukup & Tidak Baik & $\begin{array}{c}\text { Sangat } \\
\text { Tidak Baik }\end{array}$ \\
\hline Nilai & $80-100$ & $66-79$ & $56-65$ & $40-55$ & $0-39$ \\
\hline
\end{tabular}

\section{HASIL DAN DISKUSI}

\section{Tahap Persiapan (Preliminary)}

Pada tahap ini, peneliti melakukan analisis siswa dimana setelah melakukan observasi di SMPN 1 Kota Jambi yang merupakan tempat peneliti melakukan penelitian, maka diperoleh hasil observasi yakni mengenai pengetahuan, kelas, jenis kelamin dan cara belajar pada masing-masing siswa. Peneliti menggunakan sampel di kelas VIII A. Siswa yang menjadi sampel penelitian tersebut memiliki kemampuan atau pengetahuan berbeda-beda (tinggi, sedang dan rendah) yang memiliki latar belakang kemampuan atau pengetahuan yang berdeda-beda. Siswa memiliki kemampuan awal yang cukup baik mengenai materi bangun ruang sisi datar. Hal tersebut berguna sebagai kemampuan awal siswa yang dapat membantu siswa dalam mengerjakan soal-soal HOTS bangun ruang sisi datar.

Selanjutnya analisis kebutuhan soal HOTS dimana peneliti memperoleh informasi bahwa siswa 
membutuhkan soal-soal HOTS berbasis budaya Jambi yang dapat melatih siswa untuk mengerjakan soal bermuatan HOTS dengan konteks Jambi. Penggunaan konteks dalam pembelajaran matematika menjadikan konsep-konsep abstrak dapat dipahami berdasarkan pemikiran yang dibangun berdasarkan situasi realistik tertentu yang sudah dikenal dengan baik oleh siswa (Susanti, 2016).

Kebutuhan penggunaan budaya Jambi adalah mendekatkan siswa dengan budaya yang dalam penelitian ini yaitu budaya Jambi. Saat ini ada kecenderungan siswa tidak mengenali budayanya sendiri. Soal HOTS berbasis budaya Jambi dapat digunakan sebagai muatan lokal dalam pembelajaran matematika di Jambi. Harapanya dengan cara demikian juga akan menumbuhkan kecintaan siswa terhadap budaya Jambi serta melestarikan budaya tersebut.

Selanjutnya, peneliti merancang atau mendesain instrumen tes HOTS yang berbasis budaya Jambi pada materi bangun ruang sisi datar kelas VIII. Tahap awal yang dilakukan peneliti yaitu memodifikasi soal-soal HOTS yang ada agar menjadi soal-soal HOTS berbasis budaya Jambi. Peneliti mendesain kisikisi soal tes mengacu pada indikator pencapaian kompetensi dan level kognitif masing-masing soal. Setelah itu peneliti mendesain butir soal HOTS kedalam kartu soal HOTS. Selain itu peneliti juga mendesain pedoman penskoran yang digunakan untuk mempermudah peneliti, guru dan peneliti lain dalam memberikan penilaian terhadap tes HOTS yang dikerjakan siswa.

\section{Tahap Protoryping}

Expert Review (penilaian para ahli) digunakan sebagai dasar melakukan revisi dan penyempurnaan prototype. Validasi instrumen dilakukan dengan cara memberikan lembar validasi instrumen kisi-kisi tes, kartu soal tes dan kunci jawaban serta pedoman penskoran kepada validator. Validator terdiri dari 2 dosen matematika Program Magister Pendidikan Matematika Universitas Jambi. Berdasarkan penilaian validator diperoleh kesimpulan bahwa soal HOTS berbasis budaya Jambi pada materi bangun ruang sisi datar telah memenuhi indikator valid dari segi konten, konstruk, dan bahasa. Namun, masih dilakukan revisi pada Prototype $I$ atas dasar komentar dan saran dari validator. Validator menyarankan untuk menambahkan stimulus agar siswa mengetahui mengenai rumah adat Jambi. Adapun salah satu soal sebelum dan setelah revisi berdasarkan validator dapat dilihat pada Gambar 2 dan Gambar 3.

Selanjutnya dilakukan uji coba satu per satu (one-to-one) bersamaan dengan validasi oleh Expert Review, tahap ini melibatkan 3 siswa non subjek penelitian kelas VIII di SMP N 1 Kota Jambi. Soal HOTS yang berjumlah 10 butir soal dibagikan ke siswa. Siswa diminta membaca, mencermati, dan mengerjakan soal. Setelah pengerjaan soal peneliti melakukan wawancara kepada masing-masing siswa tentang kendala yang dihadapi siswa terkait aspek keterbacaan soal (bahasa), waktu yang dibutuhkan untuk menjawab soal, materi yang berhubungan dengan soal dan kendala-kendala lainnya yang dialami siswa dalam menjawab soal. Berdasarkan komentar dan saran dari one to one maka soal-soal pada Prototype 1 selanjutnya direvisi dan diperbaiki kembali sehingga menjadi Prototype 2 yang valid dan dapat di ujicobakan pada tahap selanjutnya yaitu Small Group (kelompok kecil). 


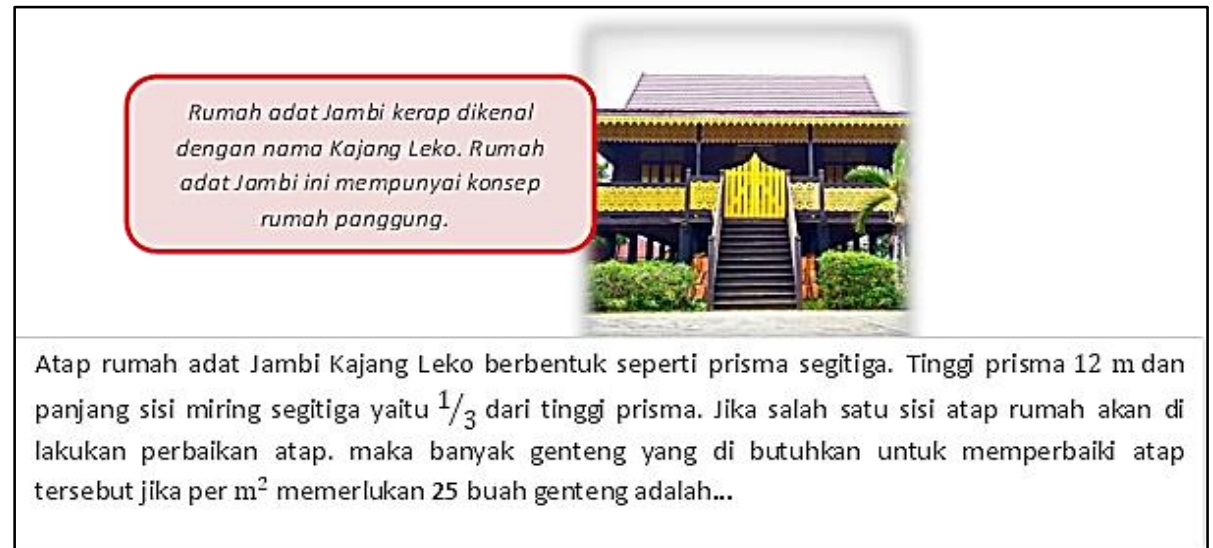

Gambar 2. Soal Nomor 8 Sebelum Revisi
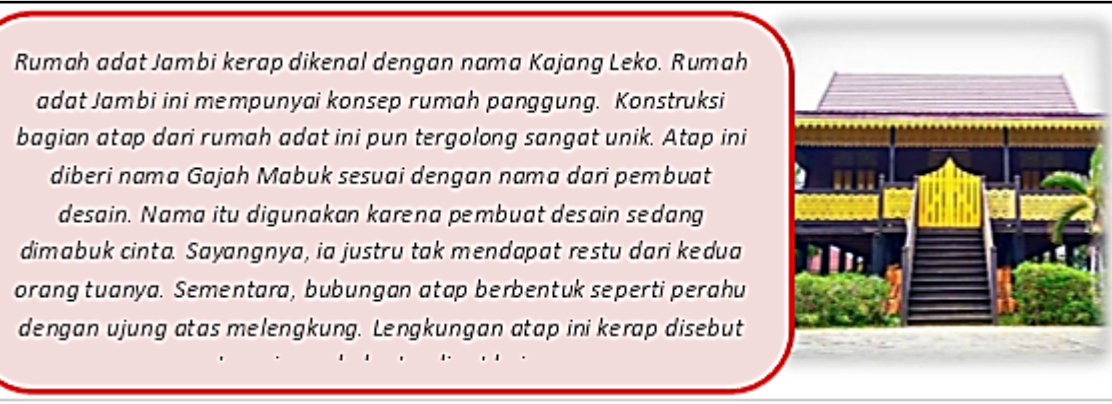

Atap rumah adat Jambi Kajang Leko berbentuk seperti prisma segitiga. Tinggi prisma $12 \mathrm{~m}$ dan panjang sisi miring segitiga yaitu $1 / 3$ dari tinggi prisma. Jika salah satu sisi atap rumah akan di lakukan perbaikan atap. maka banyak genteng yang di butuhkan untuk memperbaiki atap tersebut jika per $\mathrm{m}^{2}$ memerlukan 25 buah genteng adalah...

\section{Gambar 3. Soal Nomor 8 Sesudah Revisi}

Selanjutnya yakni uji kelompok kecil (Small Group). Tahap Small Group diujicobakan pada Tahap Small Group. Setelah mengerjakan, siswa diminta untuk menulis komentar terhadap soal yang telah dikerjakan. Kemudian siswa diberikan angket untuk mengetahui kepraktisan soal. Kepraktisan soal tergambar pada tahap Small Group dimana semua siswa dapat memahami maksud soal dengan baik, sesuai dengan alur pikiran siswa, mudah dibaca dan tidak menimbulkan penafsiran yang beragam berdasarkan angket yang diberikan peneliti kepada siswa. Data yang diperoleh dari angket dianalisis dengan menggunakan rumus yang telah ditetapkan pada bab sebelumnya. Hasil angket siswa terhadap kepraktisan soal dapat dilihat pada Tabel 4.

Tabel 4. Hasil Angket Siswa Terhadap Kepraktisan Soal

\begin{tabular}{|c|l|c|}
\hline No & Nama Responden & Jumlah Skor \\
\hline $\mathbf{1}$ & RBS & 72 \\
\hline $\mathbf{2}$ & MDA & 78 \\
\hline $\mathbf{3}$ & DHA & 71 \\
\hline $\mathbf{4}$ & NPA & 70 \\
\hline $\mathbf{5}$ & FPA & 72 \\
\hline $\mathbf{6}$ & WR & 73 \\
\hline \multicolumn{2}{|c|}{ Total Skor } & $\mathbf{4 3 6}$ \\
\hline
\end{tabular}

Data dari Tabel 4. kemudian di analisis dengan menggunakan rumus sebagai berikut: 


$$
\text { Nilai Kepraktisan }=\frac{\text { jumlah skor seluruh jawaban responden }}{\text { jumlah responden } \times \text { jumlah butir }}=\frac{436}{6 \times 18}=4,04
$$

Berdasarkan analisa nilai angket yang diperoleh yakni 4,04 maka rentang skor yang didapat termasuk dalam klasifikasi praktis. Produk yang telah dikembangkan berupa soal HOTS bangun ruang sisi data berbasis budaya Jambi dinyatakan praktis berdasarkan hasil angket kepraktisan siswa terhadap soal. Prototype 3 yang telah dinyatakan valid oleh pakar dan uji satu per satu dan praktis berdasarkan hasil angket siswa pada tahap Small Group dapat dilanjutkan ke tahap selanjutnya yaitu uji coba lapangan (Field Test).

Selanjutnya yakni uji coba lapangan (Field Test). Prototype 3 diujicobakan pada subjek uji coba penelitian yaitu siswa kelas VIII A SMP Negeri 1 Kota Jambi. Kegiatan tes dilakukan selama 3 × 30 menit. Siswa diminta untuk mengerjakan soal tes HOTS yang berisi 10 butir soal uraian. Hasil yang diperoleh dari jawaban siswa dianalisis secara deskriptif. Selain itu berdasarkan hasil pekerjaan siswa tersebut akan dianalisis untuk mengukur efek potensial siswa terhadap kemampuan dasar matematika siswa dan mampu menarik minat serta memotivasi siswa sehingga merasa tertantang untuk menyelesaikan soal-soal HOTS dan dilihat dari skor yang diperoleh siswa dalam mengerjakan soal tes yang telah dikembangkan. Berdasarkan skor hasil tes siswa dan analisis dokumen pada lembar jawaban siswa pada tahap Field Test terhadap soal-soal yang dikembangkan. Hasil skor jawaban siswa pada tahap Field Test dapat dilihat pada Tabel 5.

Tabel 5. Skor Jawaban Siswa pada Tahap Field Test

\begin{tabular}{|c|c|c|}
\hline No. & $\begin{array}{c}\text { Subjek } \\
\text { Uji Coba }\end{array}$ & Nilai \\
\hline 1 & S2 & 79.07 \\
\hline 2 & S3 & 70.54 \\
\hline 3 & S5 & 75.19 \\
\hline 4 & S6 & 77.52 \\
\hline 5 & S8 & 75.97 \\
\hline 6 & S9 & 79.07 \\
\hline 7 & S10 & 88.37 \\
\hline 8 & S11 & 79.07 \\
\hline 9 & S12 & 87.60 \\
\hline 10 & S13 & 79.07 \\
\hline 11 & S14 & 79.07 \\
\hline 12 & S15 & 72.09 \\
\hline \multicolumn{2}{|c|}{ Rata-rata } & $\mathbf{7 8 . 5 5}$ \\
\hline
\end{tabular}

Berdasarkan Tabel 5. diperoleh rata-rata nilai siswa yaitu 78.55 dimana nilai tersebut terkategori baik. Berdasarkan analisis dokumen produk yang dikembangkan memiliki efek potensial terhadap kemampuan dasar matematika siswa dan mampu menarik minat serta memotivasi siswa sehingga merasa tertantang untuk menyelesaikan soal-soal HOTS.

\section{Diskusi}

Penelitian pengembangan ini bertujuan untuk mengembangkan instrumen tes HOTS berbasis 
budaya Jambi pada materi bangun ruang sisi datar kelas VIII. Prototype 1 dihasilkan pada tahap preliminary. Prototype 2 dihasilkan pada Expert Review dan one to one. Menurut Branch, (2009), validasi ahli penting untuk dilakukan, agar produk yang dikembangkan layak untuk digunakan secara teori. Prototype 3 dihasilkan dari Small Group yang kemudian di ujikan pada tahap Field Test. Small Group penting untuk dilakukan agar mendapatkan gambaran mengenai penggunaan produk yang dikembangkan pada situasi belajar dikelas, serta untuk mendapatkan feedback dari siswa (Lestari, 2013). Prototype 3 yang dihasilkan pada penelitian ini berupa seperangkat soal HOTS bangun ruang sisi datar kelas VIII berbasis Budaya Jambi yang terdiri dari 10 butir soal uraian yang valid dan praktis.

Budaya Jambi yang di masukkan kedalam soal dijadikan sebagai stimulus soal. Stimulus bertujuan untuk merangsang siswa agar tertarik untuk mengerjakan soal. Stimulus merupakan salah satu syarat dari pembuatan soal HOTS. Stimulus yang dimasukan agar menambah wawasan peserta didik tentang budaya Jambi yang mungkin belum mereka ketahui. Hal ini berdasarkan pendapat dari Kemendikbud, (2017) dimana penggunaan stimulus yang menarik dan kontekstual adalah hal yang harus diperhatikan dalam pembuatan soal HOTS.

Berikut disajikan pembahasan jawaban siswa yang diperoleh pada saat Field Test. Soal pertama yang akan dibahas adalah soal nomor satu dengan unsur budaya Jambi yaitu makanan khas Jambi kue Padamaran. Kue Padamaran ini dipilih karna wadah dari kue tersebut berbentuk bangun ruang sisi datar yaitu balok yang mana hal tersebut terkait dengan materi dari pengembangan instrumen tes ini. Kue Penulis bermaksud memunculkan literasi matematika siswa yang berkaitan dengan salah satu hal yang paling dekat dengan keseharian peserta didik. Soal nomor satu ditampilkan pada Gambar 4.

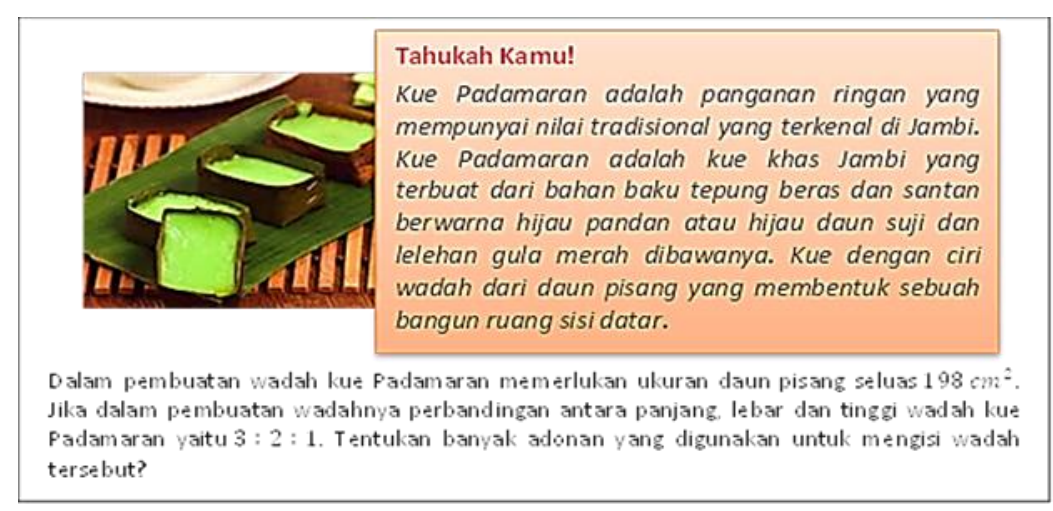

Gambar 4. Soal Nomor 1 pada Prototype 3

Soal tersebut dikembangkan dengan tujuan untuk mengaktifkan kemampuan siswa dalam bernalar dan juga melibatkan kemampuan-kemampuan lainnya. Penalaran ini dimulai dari pengamatan wadah kue yang ada (disajikan dalam gambar). Pengamatan ini diharapkan akan mencapai kesimpulan bagaimana peserta didik dapat menganalisis maksud dari soal dan memunculkan ide-ide terhadap apa yang akan mereka tuangkan. Penyelesaian soal nomor 1 ini dimana peserta didik harus mengetahui terlebih dahulu ukuran masing-masing panjang, lebar dan tinggi dari wadah kue tersebut. Jawaban ini dapat ditemukan dengan mencari ukuran wadah dari luas permukaan yang diketahui dan kemudian peserta didik dapat mengetahui banyak adonan yang diperlukan. Berikut ditampilkan pada Gambar 5 salah satu jawaban 
siswa pada soal nomor 1 yang dibahas dalam penelitian ini. Jawaban berikut adalah milik siswa 12 atau S12 (diambil dari urutan abjad nama siswa) dan dipilih secara random.

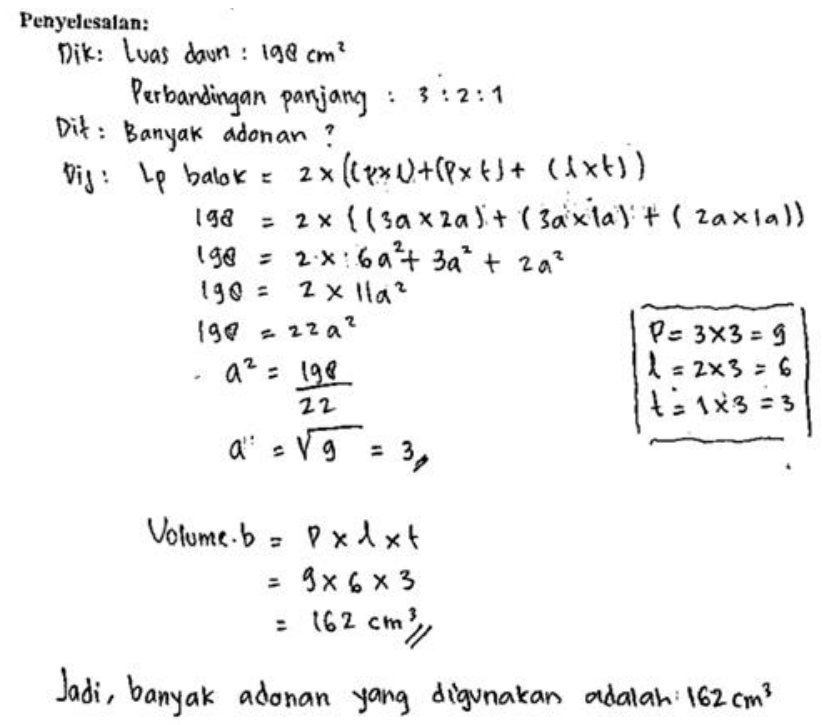

Gambar 5. Jawaban Soal Nomor 1 pada Prototype 3 oleh S12

Pada jawaban yang disajikan pada Gambar 2 tersebut, dapat dilihat bahwa siswa 12 melibatkan penalaran dalam menyelesaikan soal. Operasi matematika yang lakukan cukup baik. S12 menganalisis perbandingan ukuran yang diketahui kemudian dikaitkan dengan rumus yang ada. S12 menggunakan rumus luas permukaan untuk mencari ukuran wadah kue tersebut. Selain itu, S12 juga melibatkan kemampuan berpikir untuk memecahkan permasalahan dalam soal. Dengan menggunakan cara tersebut dalam penyelesaian soal nomor 1 ini, S12 sudah menggunakan cara penalaran dengan alur berpikir yang dibuatnya sendiri.

Penalaran matematika yang mencakup kemampuan untuk berpikir secara logis dan sistematis merupakan ranah kognitif matematik yang paling tinggi (Susanti, 2016). Penalaran merupakan suatu proses berpikir dalam pencapaian sebuah kesimpulan dari suatu pengetahuan yang dihadapi dengan cara mengaitkannya dengan pengetahuan yang telah dimiliki sebelumnya (Rizta et al., 2013). Dalam hal ini S12 mengaitkan ukuran perbandingan wadah kue dengan luas permukaan yang diketahui dalam soal dengan rumus luas permukaan dari bangun ruang tersebut. Dari hal tersebut maka akan didapatkan hasil yang akan dicapai yakni menentukan banyak adonan yang dibutuhkan dalam pembuatan kue tersebut. Berdasarkan hal ini dapat disimpulkan bahwa soal nomor 1 memiliki efek potensial berupa pengaitan penalaran dan merancang startegi untuk memecahkan masalah juga proses berpikir kritis pada siswa.

Berdasarkan lembar jawaban siswa pada tahap Field Test dan hasil angket dan wawancara yang dilakukan pada tahap Small Group diketahui bahwa siswa merasa tertarik, termotivasi dan tertantang untuk menyelesaikan soal-soal HOTS berbasis Budaya Jambi. Ketertarikan siswa terutama pada penggunaan stimulus soal yang termodifikasi dengan Budaya Jambi yang ada dalam pengembangan soal ini. 
Perangkat soal yang dikembangkan memperhatikan tiga kriteria yang diambil dari kriteria yang dikemukakan oleh (Plomp \& Nieveen, 2007) yaitu valid, praktis, dan efektif. Instrumen dikatakan valid apabila hasil validasi dari pakar mengatakan bahwa soal-soal yang dikembangkan sudah valid baik dari segi konten, konstruk, dan bahasa. Selain itu, instrumen dikatakan praktis apabila soal yang dikembangkan dapat digunakan oleh semua praktisi pendidikan matematika dan para pakar yang menjadi validator soal menyatakan bahwa soal yang dikembangkan dapat diterapkan. Menurut Akker instrumen dikatakan efektif apabila para pakar dan praktisi berdasarkan pengalamannya menyatakan bahwa instrumen (soal) mempunyai efek potensial terhadap kemampuan dasar matematika siswa dan mampu menarik minat serta memotivasi siswa sehingga merasa tertantang untuk menyelesaikan soal-soal HOTS (Rizta et al., 2013).

\section{KESIMPULAN}

Adapun kesimpulan dari penelitian ini yakni proses pengembangan instrumen tes HOTS berbasis budaya Jambi pada materi bangun ruang sisi datar kelas VIII melalui menggunakan formative evaluation yang mencakup tahap persiapan (preliminary) dan tahap prototyping yang meliputi Expert Review, one-toone, Small Group dan Field Test. Pengembangan soal HOTS meningkatkan motivasi belajar siswa karena menghubungkan materi pelajaran dengan konteks dunia nyata khususnya budaya Jambi sehingga pemebalajaran menjadi bermakna. Instrumen tes HOTS yang baik dihasilkan dari validasi yang menyatakan bahwa instrumen tes telah valid dengan mempertimbangkan aspek isi (sesuai dengan indikator materi), aspek konstruk (kesesuaian dengan karakteristik HOTS dan konteks budaya Jambi) dan aspek bahasa (sesuai EBI dan tidak mengandung penafsiran ganda). Selain itu instrumen yang baik dilihat dari kepraktisan soal dimana perangkat soal tidak berbelit-belit dan mudah dipahami siswa. Adanya gambar-gambar (ilustrasi) akan membantu memudahkan siswa dalam memecahkan permasalahan yang diberikan. Untuk peneliti selanjutnya, Produk soal yang telah dibuat dapat digunakan dalam pembelajaran khususnya materi bangun ruang sisi datar kelas VIII, karna sudah diujikan dengan benar bahwa produk soal ini baik dan bermanfaat dalam proses pembelajaran.

\section{REFERENSI}

Anderson, L. W., Krathwohl, D. R., \& Bloom, B. S. (2001). A Taxonomy for Learning, Teaching, and Assessing: A Revision of Bloom's Taxonomy of Educational Objectives. 41(4), 352. http://books.google.com/books?id=JPkXAQAAMAAJ\&pgis=1

Branch, R. (2009). Instructional Design-The ADDIE Approach. Springer.

Charmila, N., Zulkardi, Z., \& Darmawijoyo, D. (2016). Pengembangan soal matematika model PISA menggunakan Konteks Jambi. Jurnal Penelitian Dan Evaluasi Pendidikan, 20(2). https://doi.org/10.21831/pep.v20i2.7444

Heong, Y. M., Othman, W. B., Yunos, J. B. M., Kiong, T. T., Hassan, R. Bin, \& Mohamad, M. M. B. (2011). The Level of Marzano Higher Order Thinking Skillsamong Technical Education Students. 
International Journal of Social Science and Humanity, 1(2), 121-125. https://doi.org/10.7763/ijssh.2011.v1.20

Kamid, K., Fiskha Dwi Patri, S., Saharudin, S., \& Sofnidar, S. (2020). Ethnomathematical Analysis of Geometry Form in the Great Mosque of Pondok Tinggi at Sungai Penuh City and Relationship to Mathematics Instructional. 05, 15-22. www.arjhss.com

Kamid, Wandari, A., \& Rohati. (2018). Ethnomathematics analysis on Jambi plait art as the mathematics learning resources. Journal of Physics: Conference Series, 1088, 7-12. https://doi.org/10.1088/1742$6596 / 1088 / 1 / 012055$

Kemendikbud. (2017). Modul Penyusunan Higher Order Thingking Skill (HOTS).

Krathwohl, D. R. (2002). A Revision of Bloom's Taxonomy: An Overview. Theory Into Practice, 41(4), 212-218. https://doi.org/10.1207/s15430421tip4104_2

Kristanto, P. D., \& Setiawan, P. G. F. (2020). Pengembangan Soal HOTS (Higher Order Thinking Skills) Terkait Dengan KonteksPedesaan. PRISMA: Prosiding Seminar Nasional Matematika, 3, 370-376. https://journal.unnes.ac.id/sju/index.php/prisma/\%0A

Kusmaryono, I. (2012). Designing Quality Learning Landscape in Indonesia. Makalah Seminar Kemendikbud Dikti.

Lestari, I. (2013). Pengembangan Bahan Ajar Berbasis Kompetensi. Akademia Permata.

Mardhiyanti, D., Ilma, R., \& Kesumawati, N. (2013). Pengembangan Soal Matematika Model PISA Untuk Mengukur Kemampuan Komunikasi Matematis Siswa Sekolah Dasar. Jurnal Pendidikan Matematika, 5(1). https://doi.org/10.22342/jpm.5.1.334.

Masitoh, \& Aedi, W. G. (2020). Pengembangan Instrumen Asesmen Higher Order Thinking Skills (HOTS) Matematika di SMP Kelas VII. Jurnal Cendekia : Jurnal Pendidikan Matematika, 4(2).

Plomp, T., \& Nieveen, N. (2007). An Introduction to Educational Design Research.

Rachmawati, I. (2012). Eksplorasi Etnomatematika Masyarakat Sidoarjo. MATHEdunesa, 1(1).

Rizta, A., Zulkardi, Z., \& Hartono, Y. (2013). Pengembangan Soal Penalaran Model Timss Matematika Smp. Jurnal Penelitian Dan Evaluasi Pendidikan, 17(2), 230-240. https://doi.org/10.21831/pep.v17i2.1697

Rofiah, E., Nonoh, s. A., \& Ekawati, E. Y. (2013). Penyusunan Instrumen Tes Kemampuan Berpikir Tingkat Tinggi Fisika pada Siswa SMP. Jurnal Pendidikan Fisika, 1(2), 17-22.

Rosnawati, R. (2009). Enam Tahapan Aktivitas dalam Pembelajaran Matematika untuk Mendayagunakan Berpikir Tingkat Tinggi Siswa. Revitalisasi MIPA Dan Pendidikan MIPA Dalam Rangka Penguasaan.

Rusdi, M. (2018). Penelitian Desain dan Pengembangan Kependidikan. PT RajaGrafindo Persada.

Susanti, E. (2016). Pengembangan Soal Matematika Tipe Timss Menggunakan Konteks Rumah Adat Untuk Siswa Sekolah Menengah Pertama. Jurnal Pendidikan Matematika, 10(2), 1-22. https://doi.org/10.22342/jpm.10.2.3631.53-74

Sutrimo, S., Kamid, K., \& Saharudin, S. (2019). LKPD Bermuatan Inquiry dan Budaya Jambi: Efektivitas 
dalam Meningkatkan Kemampuan Berpikir Kreatif Matematis. IndoMath: Indonesia Mathematics Education, 2(1).

Tessmer, M. (2005). Planning and Conducting Formative Evaluation. Kogan Page.

Wandari, A., Kamid, K., \& Maison, M. (2018). Pengembangan Lembar Kerja Peserta Didik (LKPD) pada Materi Geometri berbasis Budaya Jambi untuk Meningkatkan Kreativitas Siswa. Edumatika: Jurnal Riset Pendidikan Matematika, 1(2), 47. https://doi.org/10.32939/ejrpm.v1i2.232

Widoyoko, E. P. (2011). Evaluasi Program Pembelajaran, Panduan Praktis bagi Pendidik dan Calon Pendidik. Pustaka Pelajar.

Widoyoko, E. P. (2020). Teknik Penyusunan Instrumen Penelitian. Pustaka Pelajar.

Zulfah, Z. (2018). Analisis Kebutuhan Pengembangan Soal Berbasis Kearifan Lokal. Jurnal Cendekia: Jurnal Pendidikan Matematika, 2(1), 1-6. https://doi.org/10.31004/cendekia.v2i1.27 